\title{
Effect of Sho-hange-ka-bukuryo-to on Gastrointestinal Peptide Concentrations in the Plasma of Healthy Human Subjects
}

\author{
Fumihiko Katagiri, * Hiroki Itoh, and Masaharu Takeyama \\ Department of Clinical Pharmacy, Oita University Hospital; Hasama-machi, Oita 879-5593, Japan. \\ Received April 26, 2004; accepted July 1, 2004
}

\begin{abstract}
Sho-hange-ka-bukuryou-to, a traditional Chinese herbal (Kampo) medicine, has been used to treat hyperemesis of pregnancy, nausea and vomiting. Most traditional herbal medicines are prepared from several herbs. For example, Sho-hange-ka-bukuryo-to is prepared from three herbs: Pinelliae Tuber, Zingiberis Rhizoma and Hoelen. Thus, to determine the precise mechanism of the pharmacological effects of Chinese herbal medicines is too difficult. So we have elucidated the effect of some Chinese herbal medicines by examining the change of the plasma levels of brain-gut peptides. In this study, we investigated the effects of Sho-hange-ka-bukuryo-to on the plasma levels of gut-regulated peptides (gastrin, somatostatin, motilin and vasoactive intestinal peptide (VIP)) and gastrointestinal mucosa regulatory neuropeptides (calcitonin gene-related peptide (CGRP) and substance P) in healthy human subjects. A single oral administration of Sho-hange-ka-bukuryo-to caused significant increases in plasma somatostatin-, CGRP- and substance P-immunoreactive substance (IS) levels, compared with a placebo group. Transient elevation of gastrin-IS levels in the placebo group was inhibited by the administration of Sho-hange-ka-bukuryo-to, but the medicine showed no effects on plasma motilin- or VIP-IS levels. In conclusion, these results might indicate that the pharmacological action of Sho-hange-ka-bukuryo-to is closely related to changes in gastrin-, somatostatin-, CGRP- and substance P-IS levels in human plasma.
\end{abstract}

Key words Sho-hange-ka-bukuryo-to; gut-regulated peptide; mucosal protective neuropeptide; Kampo

In many cases, traditional Chinese herbal (Kampo) medicines have been used in the empirical treatment of chronic hypofunction. In recent years, some Kampo medicines used to treat those experiential gastrointestinal diseases have been elucidated pharmacologically from the viewpoint of gut-regulated hormone levels. Among these medicines, Dai-kenchuto increases gastrointestinal motility and relieves bowel obstruction. These effects were reported to cause significant increases in the levels of motilin and vasoactive intestinal peptide (VIP) in human plasma. ${ }^{1-3)}$

Sho-hange-ka-bukuryo-to, a Kampo medicine, is prepared from three herbs: Pinelliae Tuber, Zingiberis Rhizoma and Hoelen. The medicine has been used for thousands years for the treatment of nausea, vomiting, acute and chronic gastritis and upper gastrointestinal function abnormalities (gastric atony). Especially, it has been widely used to treat the hyperemesis of pregnancy. Naito et al. investigated several Kampo medicines, including Pinelliae Tuber and Zingiberis Rhizoma. ${ }^{4-6)}$ Kampo medicines, such as Rikkunshi-to, Hange-shashin-to and Hange-koboku-to, usually use longterm administration to treat chronic hypofunction. But the Kampo medicines that consist of multiple herbs, such as Sho-hange-ka-bukuryo-to, are administered to treat acute hypofunction. Sho-hange-ka-bukuryo-to is often used for treatment of motion sickness or acute nausea. Furthermore, there is a report that Kampo medicines which include Pinelliae Tuber, i.e. Hange-koboku-to, Hange-shashin-to and Shohange-ka-bukuryo-to, were effective against nausea or vomiting as side effects of anticancer drugs. ${ }^{7)}$

Generally nausea or vomiting is caused by stimulation of the vomiting center located in the medulla oblongata. Vomiting is subclassified into central vomiting and reflex vomiting. The former is caused by brain hypertension (e.g. cerebral tumor, subarachnoidal hemorrhage or meningitis), stimulation from a labyrinth, vestibule or cerebellum (e.g. motor sickness and Meniere's disease), mental stimulation from the cerebral cortex (e.g. unrest, hatred, hysteria or depression) or stimulation via the chemoreceptor trigger zone (CTZ), which receives drugs (morphine, alcohol and anticancer drugs etc.), abnormalities of the metabolic or internal secretion system, bacterial toxins etc., and transmits these stimulations to the vomiting center. The latter is caused by stimulations via afferent nerves from the tongue, pharynx and internal organs (i.e. diseases related to the digestive system). Especially, vomiting is promoted by conditions that slow gastric emptying. CTZ has a dopamine $\mathrm{D}_{2}$ receptor and a 5-hydroxytriptamine (serotonin) $5-\mathrm{HT}_{3}$ receptor. These receptors are also located in the stomach or intestine, and they are assumed to regulate gastrointestinal motility. ${ }^{8}$

One of the gastrointestinal motility regulatory factors on empirical effects has been assumed to be the induction of changes in the levels of peptides (gastrin, somatostatin, motilin and VIP) in plasma. Itoh et al. reported that cisapride, a dopamine $\mathrm{D}_{2}$ receptor antagonist and nonselective serotonin $5-\mathrm{HT}_{1,3,4}$ receptor agonist, raised plasma motilin, gastrin and somatostatin, ${ }^{9}$ and mosapride, a selective serotonin $5-\mathrm{HT}_{4}$ agonist, raised motilin and gastrin. ${ }^{10)}$ On Kampo medicine, Nagano et al. investigated the effect of Daikenchu-to on gastrointestinal peptides, ${ }^{1,2)}$ and Naito et al. also reported the effects of some Kampo medicines on gastrointestinal peptides. ${ }^{4-6,11)}$ On the gastroprotective function as a neural emergency system, sensory afferent neurons in the gastrointestinal mucosa regulate neuropeptide (calcitonin gene-related peptide (CGRP), and tachykinins (substance P etc.)) levels and play various physiological roles. ${ }^{12,13)}$ Naito et al. have reported effects of Pinelliae Tuber and Zingiberis Rhizoma extracts, which are included in Sho-hange-kabukuryo-to, on plasma CGRP and substance $\mathrm{P}^{14)}$

The purpose of this study was to determine the effects of Sho-hange-ka-bukuryo-to on plasma levels of gut-regulating peptides (gastrin-, somatostatin-, motilin- and VIP- immunoreactive substance (IS)) and gastrointestinal mucosa 
regulatory neuropeptides (substance P- and CGRP-IS) in healthy subjects.

\section{MATERIALS AND METHODS}

Materials Sho-hange-ka-bukuryo-to (EK-21, lot 1XC31), prepared as a $1.7 \mathrm{~g}$ dried powder extract of Pinelliae Tuber (6.0 g), Zingiberis Rhizoma (2.0 g) and Hoelen (5.0 g) was kindly supplied by Kanebo Co., Ltd., Tokyo, Japan. The placebo was an additive of the above formulations alone.

Synthetic human gastrin I (G17), somatostatin, porcine motilin, VIP, human CGRP and its fragment (8-37) and substance $\mathrm{P}$ were purchased from the Peptide Institute (Osaka, Japan). Fragment mini gastrin I was purchased from Sigma Chemical (St. Louis, MO, U.S.A.). Motilin and VIP fragment peptide were supplied by Professor H. Yajima. (Kyoto University, Kyoto, Japan). Antiserum to gastrin (A600/R1B), VIP (A604/R1B) and CGRP were purchased from Biogenesis (Poole, U.K.), somatostatin (RA-08-108) and substance P (RA-08-095) from Cambridge Research Biochemicals (Cambridge, U.K.), and motilin (Y121) was from Yanaihara Institute (Shizuoka, Japan). All other reagents were of analytical reagent grade from commercial sources.

Subjects Five healthy male volunteers (nonsmokers), aged 24-29 years (median 28 years), 55-68 kg (median $62 \mathrm{~kg}$ ), participated in the study. Each subject received information on the scientific purpose of the study and gave written informed consent. The study was approved by the ethical committee of Oita Medical University. The subjects did not receive any medication at least one month before the study, and fasted for $2 \mathrm{~h}$ before the study commenced and during the experiments.

Study Schedule Sho-hange-ka-bukuryo-to or a placebo at a dose of $6.0 \mathrm{~g}$, were administered orally with $100 \mathrm{ml}$ water. Each subject was administered these drugs at an interval of one month. The dose of Sho-hange-ka-bukuryo-to in this study was the maximum daily dose in clinical therapy. Venous blood samples $(10 \mathrm{ml})$ were taken from a forearm vein before and at 20,40,60,90, 120, 180 and 240 min after administration of the drug (eight times). All subjects ate lunch at 11:45-12:00, and the study was carried out from 14:00 until 18:00.

Enzyme Immunoassay (EIA) of Gastrin, Somatostatin, Motilin, VIP, CGRP, Substance $\mathbf{P}$ The blood samples were placed in chilled tubes containing 500 kallikrein inhibitor units $/ \mathrm{ml}$ of aprotinin and $1.2 \mathrm{mg} / \mathrm{ml}$ of EDTA. After centrifugation, plasma samples were diluted five-fold with $4 \%$ acetic acid ( $\mathrm{pH} 4.0$ ), and loaded onto a C18 reversedphase cartridge (Sep-Pak C18; Millipore Corp., Milford, MA, U.S.A.). After washing with $4 \%$ acetic acid, plasma peptides were eluted with $70 \%$ acetonitrile in $0.5 \%$ acetic acid ( $\mathrm{pH} 4.0)$. Elutes were concentrated by spin-vacuum evaporation, lyophilized and stored at $-40{ }^{\circ} \mathrm{C}$ until assayed. The recovery of plasma gastrin-, somatostatin-, motilin-, VIP-, CGRP- and substance P-IS was $>90 \%$ with this extracting procedure (data not shown).

EIA for gastrin, ${ }^{15}$ somatostatin, ${ }^{16)}$ motilin, ${ }^{5)}$ VIP, ${ }^{17}$ CGRP $^{18)}$ and substance $\mathrm{P}^{19)}$ were performed as previously described. The assay was performed by a delayed addition method. Separation of bound and free antigen was performed on an anti-rabbit IgG (55641, ICN Pharmaceuticals, Inc., Ohio, U.S.A.) coated immunoplate (Nunc-Immuno Module Maxisorp F8, InterMed, Denmark). The fluorescent product 4-methylumbelliferon was measured with an MTP-100F microplate reader (Corona Electric, Ibaraki, Japan). Mini gastrin I, human somatostatin, porcine motilin, fragment VIP (11-28), human CGRP (8-37) and substance P were conjugated with $\beta$-D-galactosidase (Boehringer Mannheim, Mannheim, Germany) by $N$-( $\varepsilon$-maleimidocaproyloxy $)$-succimide, according to the method of Kitagawa et al. ${ }^{20)}$ The EIA for gastrin, somatostatin, motilin, VIP, CGRP and substance $\mathrm{P}$ was specific and highly sensitive to detection limits of $0.04,0.10,0.80,1.00,0.08$ and $0.4 \mathrm{fmol} /$ well, respectively.

Statistical Analysis The area under the plasma concentration-time curve from $0 \mathrm{~min}$ to $240 \mathrm{~min}$ after administration $\left(A U C_{0-240 \mathrm{~min}}\right)$ was calculated using the trapezoidal method. Results are expressed as mean \pm S.D. (pg/ml). Comparison of mean values was made by the Mann Whitney $U$ test, and $p<0.05$ was considered statistically significant.

\section{RESULTS}

The plasma gastrin-IS level-time profile after the administration of Sho-hange-ka-bukuryo-to or a placebo is shown in Fig. 1. Sho-hange-ka-bukuryo-to did not alter gastrin-IS levels during 40-240 min compared with the placebo group, but temporary elevation $(57.4 \pm 5.6 \mathrm{pg} / \mathrm{ml}$ at $20 \mathrm{~min})$ in plasma gastrin-IS levels of the placebo was significantly inhibited by Sho-hange-ka-bukuryo-to administration $(26.3 \pm$ $21.8 \mathrm{pg} / \mathrm{ml})$.

The plasma somatostatin-IS level-time profile in Shohange-ka-bukuryo-to or in the placebo is shown in Fig. 2. Sho-hange-ka-bukuryo-to caused significant increases in somatostatin-IS at 60 and $90 \mathrm{~min}(16.5 \pm 4.5 \mathrm{pg} / \mathrm{ml}$ at $60 \mathrm{~min}$,

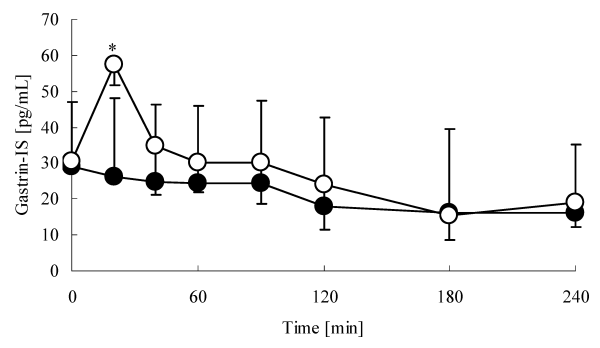

Fig. 1. Effect of Sho-hange-ka-bukuryo-to $(-)$ or Placebo $(\bigcirc)$ on Plasma Gastrin-IS Levels

Each value represents the mean \pm S.D., $n=5 . * p<0.05$, significantly different compared with placebo.

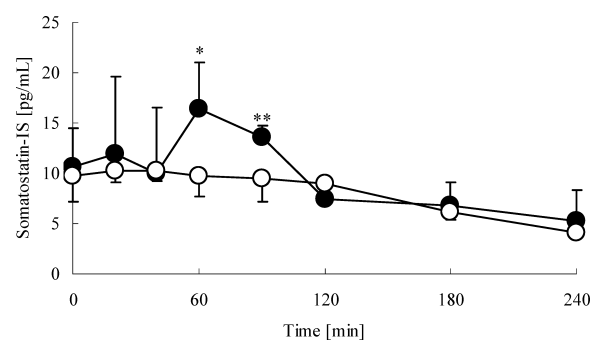

Fig. 2. Effect of Sho-hange-ka-bukuryo-to $(\mathbf{)})$ or Placebo $(\bigcirc)$ on Plasma Somatostatin-IS Levels

Each value represents the mean \pm S.D., $n=5$. $* p<0.05$ and $* * p<0.01$, significantly different compared with placebo. 


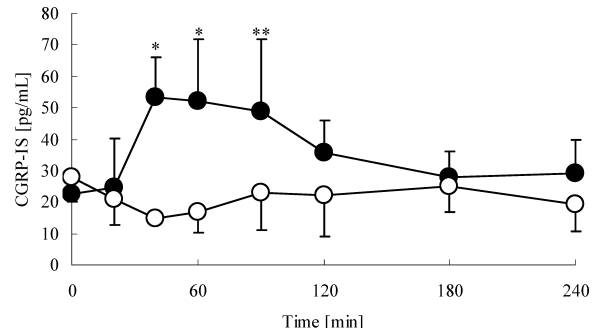

Fig. 3. Effect of Sho-hange-ka-bukuryo-to ( ) or Placebo ( $\bigcirc)$ on Plasma CGRP-IS Levels

Each value represents the mean \pm S.D., $n=5$. $* p<0.05$, significantly different compared with placebo.

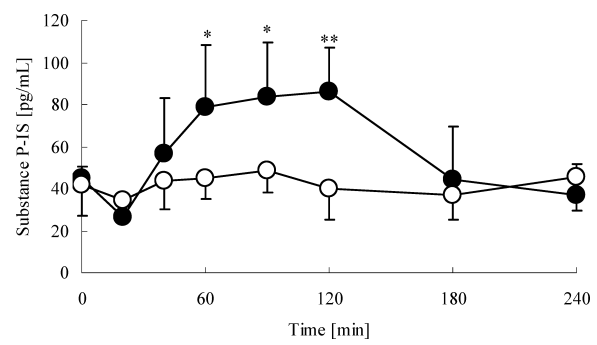

Fig. 4. Effect of Sho-hange-ka-bukuryo-to ( ) or Placebo (O) on Plasma Substance P-IS Levels

Each value represents the mean \pm S.D., $n=5 . * p<0.05$, significantly different compared with placebo.

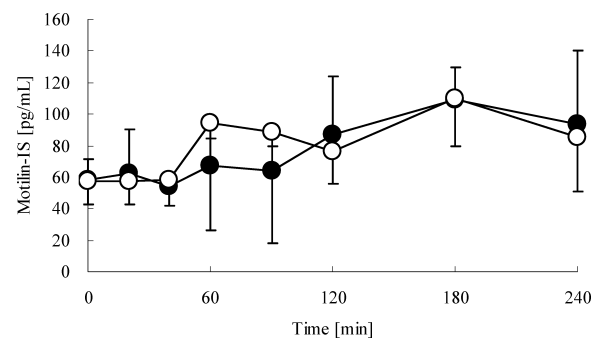

Fig. 5. Effect of Sho-hange-ka-bukuryo-to ( $)$ or Placebo $(\bigcirc)$ on Plasma Motilin-IS Level

Each value represents the mean \pm S.D., $n=5$.

$13.6 \pm 1.2 \mathrm{pg} / \mathrm{ml}$ at $90 \mathrm{~min}$ ) compared with the placebo group $(9.8 \pm 2.1 \mathrm{pg} / \mathrm{ml}$ at $60 \mathrm{~min}, 9.5 \pm 2.3 \mathrm{pg} / \mathrm{ml}$ at $90 \mathrm{~min})$.

The plasma CGRP-IS level-time profile of Sho-hange-kabukuryo-to or the placebo is shown in Fig. 3. Sho-hange-kabukuryo-to caused significant increases in CGRP-IS at 40 $90 \mathrm{~min}(53.5 \pm 12.6 \mathrm{pg} / \mathrm{ml}$ at $40 \mathrm{~min}, 52.2 \pm 19.6 \mathrm{pg} / \mathrm{ml}$ at $60 \mathrm{~min}, 48.9 \pm 22.9 \mathrm{pg} / \mathrm{ml}$ at $90 \mathrm{~min})$ compared with the placebo group $(14.9 \pm 1.9 \mathrm{pg} / \mathrm{ml}$ at $40 \mathrm{~min}, 17.0 \pm 6.6 \mathrm{pg} / \mathrm{ml}$ at $60 \mathrm{~min}, 23.0 \pm 11.8 \mathrm{pg} / \mathrm{ml}$ at $90 \mathrm{~min}$ ).

The plasma substance P-IS level-time profile of Shohange-ka-bukuryo-to or the placebo is shown in Fig. 4. Shohange-ka-bukuryo-to caused significant increases in substance P-IS at $60-120 \mathrm{~min}(78.6 \pm 29.9 \mathrm{pg} / \mathrm{ml}$ at $60 \mathrm{~min}$, $83.9 \pm 25.8 \mathrm{pg} / \mathrm{ml}$ at $90 \mathrm{~min}, 85.9 \pm 21.1 \mathrm{pg} / \mathrm{ml}$ at $120 \mathrm{~min})$ compared with the placebo group $(44.8 \pm 9.4 \mathrm{pg} / \mathrm{ml}$ at $60 \mathrm{~min}$, $48.8 \pm 10.7 \mathrm{pg} / \mathrm{ml}$ at $90 \mathrm{~min}, 39.8 \pm 14.7 \mathrm{pg} / \mathrm{ml}$ at $120 \mathrm{~min}$ ).

Sho-hange-ka-bukuryo-to had no significant effect on plasma motilin- or VIP-IS (Figs. 5, 6). The changes in plasma motilin-IS levels of both groups might reflect the ef-

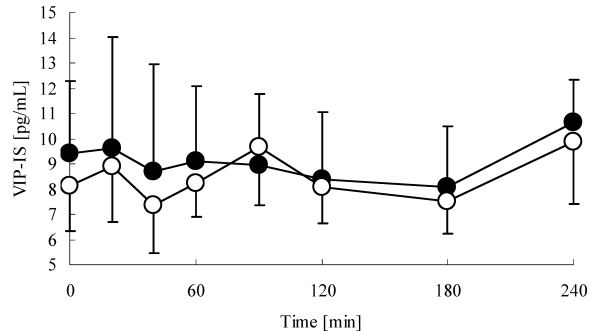

Fig. 6. Effect of Sho-hange-ka-bukuryo-to $(-)$ or Placebo $(\bigcirc)$ on Plasma VIP-IS Levels

Each value represents the mean \pm S.D., $n=5$.

Table 1. $A U C_{0-240 \min }$ of Gastrointestinal Peptide Release $(\mathrm{pg} / \mathrm{ml} \cdot \mathrm{min})$ after Administration of Sho-hange-ka-bukuryo-to or Placebo

\begin{tabular}{lcc}
\hline \hline & Placebo & $\begin{array}{c}\text { Sho-hange- } \\
\text { ka-bukuryo-to }\end{array}$ \\
\hline Gastrin-IS & $6398.4 \pm 1803.5$ & $4900.5 \pm 5359.4$ \\
Somatostatin-IS & $1928.7 \pm 122.9$ & $2266.7 \pm 301.4$ \\
VIP-IS & $2922.0 \pm 262.3$ & $3374.3 \pm 1158.5$ \\
Motilin-IS & $20481.0 \pm 5693.6$ & $19801.6 \pm 3590.6$ \\
Substance P-IS & $9923.0 \pm 2269.6$ & $14202.2 \pm 1872.3^{*}$ \\
CGRP-IS & $5187.0 \pm 964.9$ & $8706.4 \pm 919.3^{* *}$ \\
\hline
\end{tabular}

Each value represents the mean \pm S.D., $n=5 . * p<0.05$ and $* * p<0.01$, significantly different compared with placebo.

fect of periodic rhythms. Plasma VIP-IS levels in both groups remained in a low range (average, about $7.5 \mathrm{pg} / \mathrm{ml}$ ) before and after administration.

Table 1 shows the $A U C_{0-240 \text { min }}$ of gastrointestinal peptides after the administration of Sho-hange-ka-bukuryo-to or the placebo. The administration of Sho-hange-ka-bukuryo-to caused a significant increase in the $A U C_{0-240 \mathrm{~min}}$ of substance P- and CGRP-IS.

\section{DISCUSSIONS}

Sho-hange-ka-bukuryo-to is used to treat hyperemesis of pregnancy. The mechanism of hyperemesis of pregnancy is not clear, but is assumed to be related to plasma levels of estrogen or human chorionic gonadotropin, that secreted by the embryo. ${ }^{21)}$ We subjected male volunteers to this study, but considering that the mechanism of hyperemesis of pregnancy is also caused by stimulation of the vomiting center, the same as general nausea, our protocol was thought to be appropriate.

Gastrin, a 17-amino acid residue polypeptide, stimulates gastric acid secretion. This peptide is associated with a mechanism of gastrointestinal motility involving the cholinergic nervous system. ${ }^{22)}$ In Fig. 1, the temporary elevation of gastrin-IS levels of the placebo $(20 \mathrm{~min})$ might be caused by the stimulation of gastric mucosa $G$ cells. After administration of Sho-hange-ka-bukuryo-to, the temporary elevation was inhibited. Other Kampo medicines related to this Kampo medicine (i.e. Hange-shashin-to and Rikkunshi-to) increase or do not alter gastrin-IS levels. ${ }^{4,5)}$ These effects might be due to their herbs other than Pinelliae Tuber, Zingiberis Rhizoma and Hoelen, for example Aurantii Nobilis Pericarpium, which promotes of gastric acid secretion, ${ }^{23)}$ or Zizyphi Fructus, which is used as a stomachic and digestant. 
Somatostatin, a 14-amino acid residue polypeptide, inhibits the secretion of other hormones, including gastrin, insulin and motilin. ${ }^{24)}$ In the gastrointestinal tract, gastric acid and pepsin secretion and gastric emptying are inhibited by somatostatin. $^{25,26)}$ Somatostatin, which is widely distributed in the gastrointestinal tract, participates in the control of gut motility by exerting both inhibitory and stimulating influences. In other words, in the interdigestive state, somatostatin induces phase-3 activities, ${ }^{27-30)}$ and in the digestive state it inhibits gastric emptying ${ }^{31)}$ and slows gastrointestinal transit. ${ }^{32)}$ Somatostatin is the first of the gut regulatory peptides to have a significant therapeutic use. To date most clinical experience with somatostatin has been with one analogue, octreotide. ${ }^{33)}$ This analogue has a longer half-life than somatostatin, and has stimulated migrating motor complex (MMC)-like activity in the small intestine. ${ }^{34)}$ In patients with nausea or vomiting, and suffering from gastrointestinal obstruction caused by advanced cancer, the administration of octreotide, which was originally used in the treatment of gastro-entero-pancreatic endocrine tumor, improves abdominal symptoms. This peptide pharmaceutical may be useful for the treatment of intestinal dysmotility. ${ }^{35)}$ Some of these effects of peptides might correspond with experiential gastrointestinal actions of Sho-hange-ka-bukuryo-to. On gastric motility, the other Kampo medicines related to Sho-hangeka-bukuryo-to (Rikkunshi-to and Hange-shashin-to, etc.) raised somatostatin- or motilin-IS. ${ }^{2,4,5,11)}$ Compared with the herb contents of those Kampo medicines, Ginseng Radix and Aurantii Nobilis Pericarpium might be closely related to the gastric motility.

CGRP is a powerful vasoactive substance which is released from the sensory afferent nerve endings against gastric mucosal injury (caused by acid and the other noxious chemicals such as capsaicin, ethanol, etc.) in the stomach. ${ }^{6,36,37)}$ CGRP increases gastric mucosal blood flow as a gastroprotective factor. $^{38,39)}$ In this study, because Sho-hangeka-bukuryo-to raised plasma CGRP-IS levels, Sho-hange-kabukuryo-to might directly stimulate CGRP-containing nerves, or indirectly secrete CGRP accompanied by the stimulation of other secretion cells and some mechanisms.

Substance P, tachykinins, coexists with CGRP in the sensory afferent neurons of the gastrointestinal mucosa, and is released with acetylcholine in response to depolarizing stimuli in the enteric nervous system. ${ }^{40,41)}$ Substance $P$ causes direct contractions of the circular muscle in most regions of the mammalian intestine, stimulates small intestine motility and controls human small intestinal motility. ${ }^{43)}$ This peptide influences the rate of gastric emptying, too. ${ }^{43)}$

The intestine of humans is capable of organized propulsion of intraluminal contents. Propulsion of chyme or feces along the gut depends on the enteric nervous system, which coordinates slow wave activity, and on associated contractions and relaxation of the muscle layers. This coordinated propulsive activity is called peristalsis. Somatostatin and VIP are considered to relate to relaxation, whereas substance $\mathrm{P}$ is considered to relate to contractions and CGRP is considered to regulate both of them. ${ }^{44)}$ In this study, somatostatin-, CGRP- and substance P-IS levels were increased. Thus, Shohange-ka-bukuryo-to might promote the law of the intestine.

Of the herbs contained in Sho-hange-ka-bukuryo-to, Pinelliae Tuber, which includes many components (fatty acids, $\beta$-sitosterol, phenols, alkaloids and amino acids etc.), is known to have not only antiemetic effects ${ }^{45}$ but also an emetic effect. ${ }^{46)}$ But the mixture of Pinelliae Tuber and Zingiberis rhizoma has only antiemetic effects. ${ }^{47)}$ Furthermore, Pinelliae Tuber promotes intestine motility, has an antiulcer effect and inhibits gastric acid secretion. ${ }^{48-50)}$

Zingiberis rhizoma might have an effect on neuropeptides. This herb contains 6-gingerol and 6-shogaol as the main bioactive compound, both of which have vanilloid structures. Capsaicin, a vanilloid receptor agonist, stimulates capsaicinsensitive afferent neurons, which release CGRP from their nerve endings. ${ }^{13,51-53)}$ In previous reports, Zingiberis rhizoma extracts and 6-shogaol increased intestinal blood flow. ${ }^{54)}$ Furthermore, laftidine, a histamine $\mathrm{H}_{2}$ receptor antagonist which has a gastroprotective effect via the capsaicinsensitive afferent nerve, ${ }^{55}$ changed the levels of CGRP in human plasma. ${ }^{56)}$ In this study, Sho-hange-ka-bukuryo-to also raised plasma CGRP- and substance P-IS levels. We hypothesized that Sho-hange-ka-bukuryo-to might directly or indirectly increase gastric blood flow via stimulating capsaicin-sensitive afferent nerves or another pathway; as a result, it shows gastroprotective action. On the antiemesis effects of Zingiberis rhizoma, there are reports that acetone extracts of Zingiberis rhizoma were as effective on emesis as a side effect of anticancer drugs as ondansetron, a $5-\mathrm{HT}_{3}$ antagonist. ${ }^{57,58)}$

Hoelen, $90 \%$ of which is a polyglucans named pachyman, also has an antiemetic effect against copper. ${ }^{59)}$ The effect is caused by triterpenes (eburicoic acid, tumulosic acid and pachymic acid, etc.).

In conclusion, Sho-hange-ka-bukuryo-to, a Kampo medicine used to treat acute or chronic nausea and vomiting, raised plasma somatostatin-, CGRP- and substance P-IS levels and inhibited gastrin-IS levels. We hypothesized that the pharmacological effects of the drug might be closely related to these hormones and effectively accelerates the rate of gastric emptying.

\section{REFERENCES}

1) Nagano T., Itoh H., Takeyama M., Biol. Pharm. Bull., 23, 354-353 (2000).

2) Nagano T., Itoh H., Takeyama M., Biol. Pharm. Bull., 22, 1131-1133 (1999).

3) Sugiyama M., Moriwaki Y., Ito S., Hamahata Y., Fukuda N., Tanaka S., Prog. Med., 13, 1085-1088 (1993).

4) Naito T., Itoh H., Yasunaga F., Takeyama M., Biol. Pharm. Bull., 24, $841-843$ (2001).

5) Naito T., Itoh H., Yasunaga F., Takeyama M., Biol. Pharm. Bull., 25, 327-331 (2002).

6) Naito T., Itoh H., Takeyama M., Biol. Pharm. Bull., 26, 1609-1613 (2003).

7) Sato Y., Furuta N., Sanfujinka Kampo Kenkyu no Ayumi, 19, 139-143 (2002).

8) Hardman J. G., Limbird L. E., Molinoff P. B., Ruddon R. W., Gilman A. G., "The Pharmacological Basis of Therapeutics," 9th ed., McGraw-Hill Companies, Inc., U.S.A., 1996, pp. 928-934.

9) Itoh H., Nagano T., Takeyama M., Pharm. Pharmacol. Commun., 6, $533-538$ (2000).

10) Itoh H., Nagano T., Takeyama M., Biol. Pharm. Bull., 24, 1072-1075 (2001).

11) Naito T., Itoh H., Nagano T., Takeyama M., Biol. Pharm. Bull., 24, 194-196 (2001)

12) Holzer P., Gastroenterology, 114, 823-839 (1998)

13) Holzer P., Pharmacol. Rev., 43, 143-195 (1991). 
14) Naito T., Itoh H., Takeyama M., Biol. Pharm. Bull., 26, 1104-1107 (2003).

15) Takeyama M., Matsuo H., Mori K., Chem. Pharm. Bull., 41, 21972199 (1993).

16) Takeyama M., Yanaga N., Yarimizu K., Ono J., Takaki R., Fujii N., Yajima H., Chem. Pharm. Bull., 38, 456- 459 (1990).

17) Takeyama M., Wakayama K., Takayama F., Kondo K., Fujii N., Yajima H., Chem. Pharm. Bull., 38, 960-962 (1990).

18) Nagano T., Ikawa K., Takeyama M., Jpn. J. Hosp. Pharm., 24, 363369 (1998).

19) Takeyama M., Yanaga N., Yarimizu K., Ono J., Takaki R., Fujii N., Yajima H., Chem. Pharm. Bull., 38, 456- 459 (1990).

20) Kitagawa T., Shimozono T., Aikawa T., Yoshida T., Nishimura H., Chem. Pharm. Bull., 29, 1130-1135 (1981).

21) Jernfelt-Samsioe A., Obstet. Gynecol. Surv., 42, 422- 427 (1987).

22) Szelenyi I., Experientia, 36, 973-974 (1980).

23) Ikuta M., Osaka Igakkai Zasshi, 39, 2072 (1940).

24) Ling N., Burgus R., Rivier J., Vale W., Brazeau P., Biochem. Biophys. Res., 50, 127-133 (1973).

25) Schrumpf E., Adv. Exp. Med. Biol., 106, 235-240 (1978).

26) Vale W., Rivier C., Brown M., Ann. Rev. Physiol., 39, 473-527 (1977).

27) Peeters T. L., Janssens J., Vantrappen G. R., Regul. Pept., 5, 209-217 (1983).

28) Poitras P., Steinbach J. H., VanDeventer G., Code C. F., Walsh J. H., Am. J. Physiol., 239, G215-220 (1980).

29) Thor P., Krol R., Kounturek S. J., Coy D. H., Schally A. V., Am. J. Physiol., 235, E249-254, (1978).

30) Hostein J., Janssens J., Vantrappen G., Peeters T. L., Vandeweerd M., Leman G., Gastroenterology, 87, 1004-1008 (1984).

31) Seal A., Yamada T., Debas H., Hollinshead J., Osadchey B., Aponte G., Walsh J., Am. J. Physiol., 243, G97-102 (1982).

32) Johanssson C., Efendic S., Wisen O., Uvnas-allensten S., Luft R., Scand. J. Gastroenterol., 13, 481- 483 (1978).

33) Shulkes A., Baillieres Clin. Endocrinol. Metab., 8, 215-236 (1994).

34) Soudah H. C., Hasler W. L., Owyang C., N. Engl. J. Med., 325, 14611467 (1991).

35) Verne G. N., Eaker E. Y., Hardy E., Sninsky C. A., Dig. Dis. Sci., 40, 1892-1901 (1995).

36) Kinoshita Y., Inui T., Chiba T., J. Clin. Gastroenterol., 17, S27-32
(1993).

37) Yeoh K. G., Kang J. Y., Yap I., Guan R., Tan C. C., Wee A., Tenf C. H., Dig. Dis. Sci., 40, 580 - 583 (1995).

38) Holzer P., Livingston E. H., Saria A., Guth P. H., Am. J. Physiol., 260, G363-370 (1991).

39) Lambrecht N., Burchert M., Respondek M., Muller K. M., Peskar B. M., Gastroenterology, 104, 1371-1380 (1993).

40) Hellström P. M., Soder O., Theodorsson E., Gastroenterology, 100 $431-440$ (1991).

41) Schmidt P., Rasmussen T. N., Holst J. J., J. Auton. Nerv. Syst., 38, 8596 (1992).

42) Lördal M., Theodorsson E., Hellström P. M., Dig. Dis. Sci., 42, 1940-1949 (1997).

43) Mangel A. W., Koegel A., Am. J. Physiol., 246, G342-345 (1984)

44) Grider J. R., J. Pharmacol. Exp. Ther., 307, 460- 467 (2003).

45) Maki T., Takahashi K., Shibata S., Planta Med., 53, $410-414$ (1987).

46) Takahashi K., Okuyama T., Gendai Toyo Igaku, 16, $92-97$ (1995).

47) Niijima A., Kubo M., Hashimoto K., Komatsu Y., Maruno M., Okada M., Neurosci. Lett., 258, 5-8 (1998).

48) Kasahara Y., Saito E., Hinoki H., Shoyakugaku Zasshi, 37, 73-83 (1983).

49) Kasahara Y., Hinoki H., Shoyakugaku Zasshi, 37, 367 (1983).

50) Kasahara Y., Hinoki H., Shoyakugaku Zasshi, 38, 102 (1984).

51) Chen R. Y., Li D. S., Guth P. H., Am. J. Physiol., 262, H1350-1355 (1992).

52) Li D. S., Raybould H. E., Quintero E., Guth P. H., Am. J. Physiol., 261, G657-661 (1991).

53) Szallasi A., Gen. Pharmacol., 25, 223-243 (1994).

54) Murata P., Kase Y., Ishige A., Sasaki H., Kurosawa S., Nakamura T., Life Sci., 70, 2061-2070 (2002).

55) Onodera S., Shibata M., Tanaka M., Jpn. J. Pharmacol., 68, 161-173 (1995).

56) Itoh H., Naito T., Takeyama M., Biol. Pharm. Bull., 25, 379-382 (2002).

57) Sharma S. S., Gupta Y. K., J. Ethnopharmacol., 62, 49-55 (1998).

58) Sharma S. S., Kochupillai V, Gupta Y. K., Seth S. D., Gupta Y. K., J. Ethnopharmacol., 57, 93-96 (1997).

59) Tai T., Akita Y., Kinoshita K., Koyama K., Takahashi K., Watanabe K., Planta Med., 61, 527-530 (1995). 